\title{
Training Effectiveness: Transfer Strategies, Perception of Support and Worker Commitment as Predictors
}

\section{Eficacia Formativa: Estrategias de Transferencia, Percepción del Apoyo y Compromiso del Trabajador como Predictores}

\author{
Ronaldo Pilati and Jairo E. Borges-Andrade \\ University of Brasilia
}

\begin{abstract}
Evaluation of training programs has received special research attention. Testing a training effectiveness model with the trainee's characteristics and work environment factors as predictors is the goal of the present study. A survey with 652 ex-trainees in a banking institution was conducted. The results show a model with a good fit. Effect sizes of ex-trainee strategies for the transfer of learning, perception of the organization's support for this transfer and work commitment were significant predictors of training effectiveness. These findings suggest that ex-trainees who act proactively, in the post-training work environment, report more training effectiveness at work. They also suggest that the presence of transfer support and higher work commitment are related with more training effectiveness. The interaction between dispositional and contextual variables is relevant to the development of a theory of training effectiveness on work.

Keywords: effectiveness of training at work, learning transfer strategies, perception of organizational support for learning transfer, organizational psychology, Brazil, Latin America.
\end{abstract}

Resumen. La evaluación de los programas formativos ha recibido atención especial de la investigación. El objetivo del presente trabajo es testar un modelo de evaluación de la eficacia formativa con las características del formando y factores contextuales como predictores. Se facilitó una encuesta a 652 formados de una institución financiera. El resultado demuestra un modelo ajustado y el efecto de las estrategias para la creación de condiciones para la transferencia, la percepción del apoyo de la organización y el compromiso laboral como predictores significativos de la eficacia formativa. Estas conclusiones sugieren que los formados que actúan proactivamente en el ámbito laboral reportan mayor eficacia formativa en el trabajo. Así mismo sugiere que la presencia de apoyo a la transferencia y un mayor compromiso laboral se relacionan directamente con una mayor eficacia formativa. La interacción entre las variables individuales y contextuales es relevante para el desarrollo de la teoría de la eficacia formativa.

Palabras clave: eficacia formativa en el trabajo, estrategias de transferencia de aprendizaje, percepción del apoyo organizacional a la transferencia de aprendizaje, psicología organizativa, Brasil, Latinoamérica.

Training, development, and education (TD\&E) produce ... "clear benefits for individuals and teams, organizations, and society." (Aguinis \& Kraiger, 2009, p. 452).However, these benefits must be evaluated and there are several ways to do it. Sometimes these ways are too complex and spend so much time and effort that evaluation seems to be a too expensive technological development, given the frugality of resources that might have been invested in TD\&E processes. Since evaluation models are (or should be) based on how professionals or researchers understand these processes (Borges-Andrade, 2006), efforts should be made in

This research was supported by grants from CAPES (Coordination for the Development of University Level Personnel) and PRONEX (Support Program for Centers of Excellence). Correspondence concerning this article should be addressed to Ronaldo Pilati, Departamento de Psicologia Social e do Trabalho, Universidade de Brasília, Campus Darcy Ribeiro, Asa Norte, Brasília, DF. CEP: 70910-900, Brasil. Email:rpilati@unb.br order to build parsimonious theories of training effectiveness. In order to achieve such long term goal, the present article reports an empirical test of a model of training effectiveness.

TD\&E evaluation models may be classified into two large groups: (a) generic models, in which sets of variables are cumulatively related to TD\&E processes, that usually provide guiding elements for the understanding of these processes and influence research and professional actions in the area (e.g. Borges-Andrade, 2006; Goldstein, 1993; Kirkpatrick, 1976); and (b) specific models, which are based on generic models, that are built for testing relationships of a group of specific variables with individual and organizational level outcomes of TD\&E (e.g. Abbad, 1999; Axtell, Maitlis \& Yearta, 2000; Holton III, Bates, Seyler \& Carvalho, 1997). The former models are used as organizers for researchers and professionals, while the latter propose the empirical test of relationships among variables.

Transfer of learning to work or "behavior at work", 
as TD\&E outcomes, have been the focus of several research studies based on these models. Baldwin and Ford (1988) define transfer of training as the extension in which competencies are acquired in a training program and then applied, generalized and maintained for a certain amount of time in the work environment. A training action promotes the acquisition of competencies, which is followed by retention; generalization for new situations; transfer of learning; and, at the end of the chain, impact of training on work (Pilati \& Abbad, 2005). These two authors defend that training outcomes do not have a causal relationship among them, since each one is associated with multiple antecedent factors, and propose a graphic scheme which suggests limits and relationships in this chain of outcomes (Figure 1).

Figure 1. Conceptual diagram for the effects of training in multiple stages at the individual level

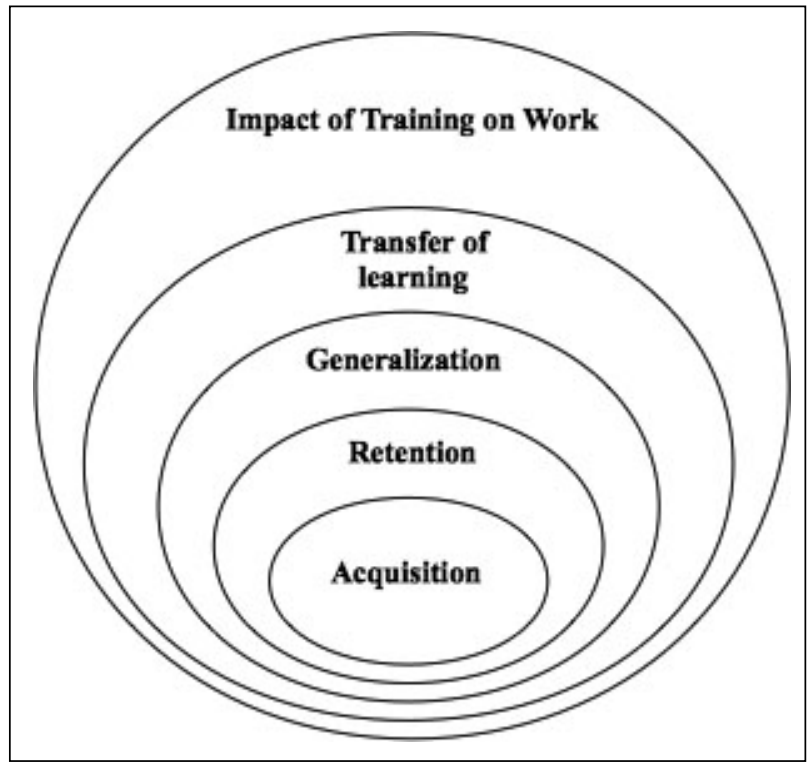

The study of training outcomes at the individual level may provide crucial information for supporting specific models, which in turn lead to the development of generic models and eventually to the formulation of technologies for effective training and management of human behavior at work. Training outcomes are key indicators for the evaluation of effectiveness and are strongly associated to several antecedent variables.

\section{Antecedents of effectiveness of training on work}

Antecedents of the effectiveness of training on work are usually classified in categories such as participant's characteristics ( $e g$. trainee's attitudes, values, and personality, among other dispositional traits), training methods (or instructional features), and situational variables. The combination of these variables often results in theoretical models that lack parsimony. A meta-analysis of studies on training evaluation between the years 1960 and 2000 found relevant evidence to the post-training environment for the comprehension of the effectiveness of the TD\&E actions (Arthur Jr., Bennet Jr., Edens \& Bell, 2003). This is an important and consistent empirical finding reported in reviews of literature (e.g. Aguinis \& Kraiger, 2009; Salas \& Cannon-Bowers, 2001).

The perception of climate for transfer has been referred as an important predictor of training transfer (Holton III, Bates, Seyler \& Carvalho, 1997; Roullier $\&$ Goldstein, 1993). This notion of perception of climate is associated with the concept of perception of support for the transfer of training. The latter has been considered a more accurate describer of the environmental characteristics of the post-training context at the individual level (Abbad, 1999). She developed a conceptual analysis of the perceptions of climate and support, based on the assumptions of the philosophy of language (Ryle, 1949), and concluded that the latter describes the phenomenon in a more parsimonious manner, less likely to overlap with other concepts. Her study has shown that perception of support for the transfer of learning is crucial for the effectiveness of $\mathrm{TD} \& \mathrm{E}$ at the individual level.

The participant's characteristics have been highlighted as relevant predictors of the effectiveness of TD\&E (Birdi, Allan \& Warr, 1997).A positive predictive relationship for career commitment in a group of executives has been reported (Cheng \& Ho, 2001) and positive and negative predictive relationships were respectively found with affective organizational and career commitments, moderated by the obligation to participate in training (Rodrigues, 2000). However, organizational commitment has not been as well studied as other participant's characteristics, as a predictor of training effectiveness.

The ex-trainee role in the post-training environment has also been shown to be a relevant predictor of the effectiveness of TD\&E (e.g. Burke, 1997; Gist, Stevens \& Bavetta, 1991; Hutchins \& Burke, 2006; Latham \& Heslin, 2003; Milne, Westerman \& Hanner, 2002; Morin \& Latham, 2000; Richman-Hirsch, 2001; Stevens \& Gist, 1997; Wexley \& Baldwin, 1986). A model of relapse prevention (Marx, 1982) may greatly help to describe the ex-trainees as promoters of the application of learning after training, who can develop strategies to apply, at work, what they have learned during training (Pilati \& Borges-Andrade, 2005). These authors have discussed the concept and developed an instrument for the measurement of such strategies and found evidence for the empirical validity of the proposed construct. Further evidences of its empirical validity have been demonstrated in other cultural contexts (Pilati \& Palomero, 2009). However, no study has yet demonstrated relationships between these measures of application strategies and training effectiveness and perception of support. The test of these relationships is one of the aims of this study. 
The present article mainly aims at investigating a predictive model for the effectiveness of training at work with the following antecedent variables: 1) commitment at work, 2) perception of support for the transfer of training and 3) strategies for applying at work what has been learned in a training program. Commitment at work is understood as a stable job attitude, that won $t$ suffer influence from the training program and that will produce more training transfer, since a positive attitude towards the job may increase the motivation to apply new learned skills. For their turn, perception of support for transfer of training and a proactive action over the post-training environment can synergistically produce more training transfer. To the best of our knowledge, there is no published empirical evidence testing the simultaneous predictive influence of these variables. Therefore, this may constitute an important contribution to the theoretical comprehension of training effectiveness. Given the abovementioned model, six hypotheses are formulated, in order to test specific relationships among those variables.

Hypthesis 1: Commitment at work before training will have a positive relationship with commitment after training.

This hypothesis is based on the well known correlates of commitment: motivation engagement, satisfaction and commitment itself, in later occasions (e.g. Cooper-Hakin \& Viswesvaran, 2005; Klein, Becker \& Meyer, 2009), which may sustain the assumption that commitment is consistent over time, as well as other job attitudes. When the relevant predictors of commitment are mentioned by authors, participation in training seldom appears as a significant predictor, which allows to the conclusion that commitment should not be considered as an indicator of training effectiveness. Furthermore, the type of training evaluated in the present investigation would not probably change a stable attitude such as commitment in the studied organization.

Hypthesis 2: Commitment at work after training will be a positive predictor of the perception of support for transfer.

Commitment, as a dispositional trait, will increase the probability that trainees develop positive perceptions of their organizational environment, including the specific perception of support for transfer. Previous studies have demonstrated that a favorable attitude towards work is positively related to organizational support (Borges-Andrade \& Pilati, 2001). Given the influence of attitudes on perceptual processes, a positive attitude would be related to more perception of support.

Hypthesis 3: Commitment at work after training will be a predictor of indicators of training effectiveness.
This same job attitude, after training, will also predict the indicators of training effectiveness. Organizational citizenship has been mentioned as one of the major consequences of commitment, along with withdrawal intentions and behaviors and lesser stress (e.g. Cooper-Hakin \& Viswesvaran, 2005; Klein, Becker \& Meyer, 2009). The decision to use, at work, what has been learned in training may be considered as an aspect of organizational citizenship. Most employers never include learning transfer as an expected performance at work and most performance evaluation models and methods do not include items related to this transfer. Few studies that relate commitment at work and effectiveness of training have been reported. In a general way, some evidence has been reported (e.g. Cheng \& Ho, 2001; Rodrigues, 2000), illuminating the positive relationship between work commitment and training effectiveness. A positive attitude will stimulate intentions to apply the new skills on the job, working as a motivational variable.

Hypthesis 4: Perception of support for the transfer of training will be a negative predictor of application strategies for what was learned in the post-training environment.

The scale of application strategies was described by Pilati and Borges-Andrade (2005) based on a model of relapse prevention or self management after training (Marx, 1982). If the organization provides support for transfer and if this is perceived by the extrainees, they will not develop efforts in order to organize and use application strategies. On the other hand, in high risk situations, such as those of lack of support for transfer, these strategies would frequently appear. Therefore, if the trainees have a low perception of support for transfer, they will apply more strategies in order to create support conditions for training transfer.

Hypthesis 5: Strategies for the application of what was learned will be a positive predictor for indicators of the effectiveness of training.

Activating self management, or using those application strategies, would supposedly increase the effectiveness of training in the organizational context. The active role of the trainee in the post-training environment is a relevant factor for the effect of training at work, according to Burke (1997) and Gist, Stevens and Bavetta (1991).

Hypthesis 6: Perception of support for training transfer will be a positive predictor for indicators of training effectiveness.

Training effectiveness, however, would hardly depend only on self management by extrainees. On the contrary, it would be highly associated to perception of 
organizational support for transfer. This association is based on well accumulated successive evidences (e.g. Abbad, Pilati \& Pantoja, 2003; Aguinis \& Kraiger, 2009; Salas \& Cannon-Bowers, 2001).

\section{Method}

\section{Participants}

Participants in this study were 652 employees of a Brazilian banking institution, with national coverage, who were trainees of 17 different training programs. Respondents were $61 \%$ males and $62.3 \%$ married and $61 \%$ had children and $44 \%$ had finished college. The average age of the sample was 37.7 years old $(\mathrm{SD}=$ 8.73), the average time of professional experience was 18.3 years $(\mathrm{SD}=8.8)$, and the average time at the bank was 13.3 years $(\mathrm{SD}=9.2)$.

\section{Measures}

Instruments that had been developed and validated in previous studies in Brazil were used. They were included in self-report questionnaires, which contained general instructions about how to fill them out, as well as information on the volunteer status of the study and anonymity of reports. The data were submitted to Confirmatory Factor Analysis (CFA). The estimation method used to test the measurement model was ADF (Asymptotically Distribution Free) due to the absence of multivariate normality of data.

Commitment at work was measured by the Brazilian version of organizational commitment scale of Mowday, Steers and Porter (1979) and by the career commitment scale of Blau (1985). Both scales were translated and validated by Bastos (1998) and have been intensively and successively used by him and by several independent Brazilian authors, in different organizational contexts and regions of the Country. The CFA structural test was first done with one latent second order affective factor, commitment at work, and two latent first order factors: organizational and career commitments. The scale possessed 16 items associated to a 7-points agreement scale (1-Totally disagree; 7 - Totally agree): 9 for organizational commitment and 7 for career commitment. This instrument obtained a good goodness of fit on its first application, T1 (RMSEA $=.055$ ), with factor loadings varying from 0.696 to 0.903 . In T2, the indices were also adequate (RMSEA $=.075)$, with factor loadings varying from 0.864 to 1.056 . The reliability of organizational commitment in $\mathrm{T} 1$ was .90 and .93 in T2. Organiza-tional commitment sample items: I feel proud to work in my organization; I am really interested in the future of my organization. The reliability for career commitment in T1 was .82 and in T2 was .81. Career commitment sample items: If I had enough money to live I would keep working in my career; I like too much my career to quit it.

Perception of support for transfer of training was measured with Abbad's (1999) scale, developed and successively used by her and by several independent Brazilian authors, in different organizational contexts and regions of the Country. This instrument also had a second order factorial structure, with a latent second order factor, and two latent first order factors: psychosocial and material support. The scale for perception of psychosocial support had 17 items and the perception of material support had 5 items all associated to a 7-point frequency scale (1 - Never; 7 - Always). This instrument had a good goodness of fit indicator $(\mathrm{RMSEA}=.081)$ with factor loadings varying from 0.380 to 0.900 . The reliability of psychosocial support was .96. Sample items of psychosocial support: I have had opportunities to apply in my job what I learned in training; My colleagues support my actions to apply the new skills. The reliability of material support was .89. Sample items of material support: My organization gives me resources to apply on the job the abilities I learned on training; My organization offers extra financial support to apply the new skills.

Strategies for application at work of what was learned during the training program were measured with the scale developed and validated by Pilati and Borges-Andrade (2005). The empirically tested structure had one latent second order factor, with two latent first order factors. The first, called behavioral strategies, had 10 items. The second, cognitive-affective strategies, had nine items. All items were associated to a 7-point frequency scale (1 - Never; 7 -Always). The instrument had a good goodness of fit index $(\mathrm{RMSEA}=.084)$, with factor loadings varying from 0.478 to 1.110 . The reliability of behavioral strategies was .94. Sample Items of the behavioral strategies factor: I believe it is possible to apply what I learned in training; I evaluate how I am applying what I learned in training. The reliability of the cognitive-affective strategies factor was .92. Sample items of cognitive-affective strategies factor: I negotiate with my supervisor the extra time necessary to apply the new skills; I ask to my supervisor to define goals to apply what I learned in training.

Effectiveness of training was assessed by two scales. These scales have only had first order structures. The first scale is for the impact of training in amplitude, developed by Abbad, Borges-Andrade and Sallorenzo (2004) with 12 items associated to a 7-points agreement scale (1-Totally disagree; 7 Total agree). This scale has also been successively used by these two first authors and by several independent Brazilian authors, in different organizational contexts and regions of the Country. It had a good goodness of fit index (RMSEA $=.070$ ), with factor loadings varying from 0.528 to 0.789 and reliability of .89. Sample items: The quality of my job improved 
after training; After training I've been suggesting changes in my tasks. The second measure concerns in depth impact, especially developed for each of the training programs that were evaluated. All items of all scales were associated to a 7-point frequency scale (1 - Never; 7 - Always). Given that this scale had to be specific for each training program, because it is based on the competencies aimed at each training course, it could not be submitted to a CFA process.

\section{Procedures}

The data were collected in two moments: the first day of training (T1); and three months after training
(T2). A technician from the training evaluation area was responsible for the national coordination of data collection, since the studied bank has branches all over Brazil. Locals were responsible for the T1 data collection. At T2, the questionnaire was directly sent to study participants in their workplaces, based on the information they gave at T1. They directly returned it to the research team. In T1 a total of 1,241 employees participated. For the purpose of this study, only the 652 who completed the questionnaires in both times (T1 and T2) were considered. The commitment measures were applied in T1, and all other measures were applied in T2. The test of stability of the commitment construct was made before the training. All other variables were evaluations of features of post-training environment.

Figure 2. Pictorial representation of the structural model for training effectiveness at work (estimated coefficients are presented in Table 2)

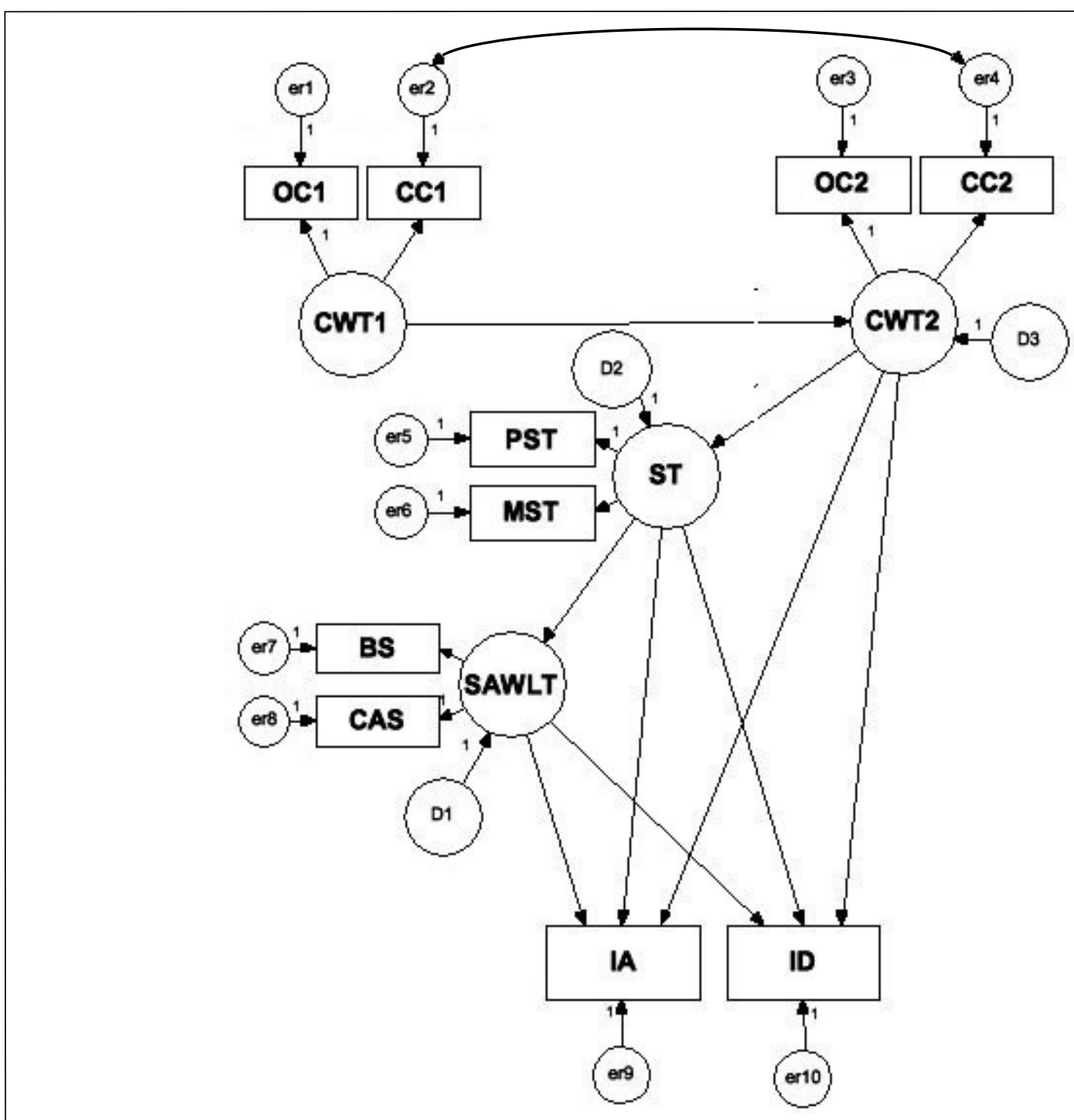

CWT1 - Commitment at Work before Training T1; OC1 - Organizational Commitment T1; CC1 - Career Commitment T1; CWT2 - Commitment at Work after Training T2; OC2 - Organizational Commitment T2; CC2 - Career Commitment T2; ST - Transfer Support; MST - Material Support for Transfer; PST - Psychosocial Support for Transfer; SAWLT - Strategies for the Application at Work of what was Learned during Training; BS - Behavioral Strategies; CAS - Cognitive-Affective Strategies; IA - Impact in Amplitude; ID - Impact in Depth. 
The commitment measure was repeated in $\mathrm{T} 2$.

Most training courses $(n=17)$ had their objectives focused on behaviors at work such as identification of fake money or dealing with clients. Some training courses were designed in order to develop skills to work with personal finances, developing a type of skills which could be applied in a broad spectrum of the trainee's life.

Data analysis for structural equation modeling was done according to the principles presented by different authors (e.g. Arbukle \& Worthke, 1999; Bollen, 1990; Boomsma, 2000; Byrne, 2001; Kaplan, 2000; McDonald \& Ho, 2002). Exploratory analyses were done to verify fulfillment of assumptions of the general linear model, according to the recommendations by Tabachnick and Fidell (2001).

The AMOS v. 7.0 program was used for structural equation modeling. Various indices such as regression coefficients among the model variables, comparative goodness of fit indices (i.e. CFI and GFI), and indices of residuals or close adjustment (i.e. RMR and RMSEA) were obtained. Goodness of fit criteria were above .90 for GFI and CFI and inferior or near .08 for the RMSEA. The stability of the relationships found in the model was tested by bootstrap replication (Efron \& Tibshirani, 1993) in 500 samples.

The analysis of the data considered only the latent second order variables, i.e. Commitment at Work, Transfer Support, and Application Strategies. This test and the test of the empirical structure of the scales have demonstrated high levels of goodness of fit. As a result, the scale items were suppressed in the final model, in order to achieve a better model identification. The effectiveness indicators were inserted in the model test as observed variables through their respective factor scores. In this test, transformations of the variables were done following Osborne's (2002) recommendations in order to comply with the assumptions of data multivariate normality (Mardia, 1971).
The missing data were dealt with using Little and Rubin's (1987) criteria. These represented a small portion of the sample (less than $3 \%$ of the total) and were at random. A mean imputation was done.

\section{Results}

The tested structural model is presented in Figure 2. CWT1 (Commitment at Work before Training) includes Organizational Commitment (OC1) and Career Commitment (CC1) associated to it. CWT2 (Commitment at Work after Training) includes OC2 and $\mathrm{CC} 2$ (respectively equivalent to $\mathrm{OC} 1$ and $\mathrm{CC} 1$ ). ST (Transfer Support) incorporates MST (Material Support for Transfer) and PST (Psychosocial Support for Transfer). The latent variable SAWLT (Strategies for the Application at Work of what was Learned during Training) is composed by BS (Behavioral Strategies) and CAS (Cognitive-Affective Strategies). Measures of training effectiveness at work are IA (Impact in Amplitude) and ID (Impact in Depth).

Table 1 presents the correlation matrix for the observed variables in the study, which was the basis for structural analysis test of the model of training effectiveness at work.

The relationships among the model's antecedent variables are shown in the first three lines of Table 2. CWT1 (Commitment at Work before Training) had a higher predictive magnitude over CWT2 (Commitment at Work after Training), which corroborates the first hypothesis. CWT2 was a significant predictor of ST (Transfer Support) with a moderate predictive magnitude, corroborating the second hypothesis.

The predictive relationships of the criterion variables are presented in the last nine lines of Table 2. The predictions of CWT2 over ID (Impact in Depth), ST over IA (Impact in Amplitude) and ID were not significant. The largest predictive effects on the criterion

Table 1. Bivariate correlation matrix, means and standard deviations between observed variables in the model

\begin{tabular}{|c|c|c|c|c|c|c|c|c|c|c|}
\hline & 1 & 2 & 3 & 4 & 5 & 6 & 7 & 8 & 9 & 10 \\
\hline 1. OC1 & - & & & & & & & & & \\
\hline 2. $\mathrm{CC} 1$ & $.64 * *$ & - & & & & & & & & \\
\hline 3. CAS & $.15^{* *}$ & $.14 * *$ & - & & & & & & & \\
\hline 4. BS & $.31 * *$ & $.23^{* *}$ & $.70 * *$ & - & & & & & & \\
\hline 5. PST & $.30 * *$ & $.20 * *$ & $.61^{* *}$ & $.70^{* *}$ & - & & & & & \\
\hline 6. MST & $.13 * *$ & .06 & $.09 *$ & $.19 * *$ & $.30^{* *}$ & - & & & & \\
\hline 7. $\mathrm{OC} 2$ & $.78 * *$ & $.59 * *$ & $.22 * *$ & $.38^{* *}$ & $.39 * *$ & $.15^{* *}$ & - & & & \\
\hline 8. $\mathrm{CC} 2$ & $.59 * *$ & $.68^{* *}$ & $.21 * *$ & $.27 * *$ & $.31 * *$ & $.10^{*}$ & $.71^{* *}$ & - & & \\
\hline 9. IA & $.39 * *$ & $.28 * *$ & $.56^{* *}$ & $.73^{* *}$ & $.62 * *$ & $.19 * *$ & $.44 * *$ & $.33 * *$ & - & \\
\hline 10. ID & $.23 * *$ & $.10 *$ & $.51 * *$ & $.67 * *$ & $.56 * *$ & $.15^{* *}$ & $.29^{* *}$ & $.21 * *$ & $.59^{* *}$ & - \\
\hline M & 5.79 & 4.72 & 3.90 & 5.24 & 4.50 & 4.90 & 5.76 & 4.69 & 5.54 & 4.92 \\
\hline SD & 0.81 & 1.14 & 1.26 & 0.94 & 1.10 & 0.93 & 0.90 & 1.28 & 0.78 & 1.40 \\
\hline
\end{tabular}

Note. OC1 - Organizational Commitment T1; CC1 - Career Commitment T1; OC2 - Organizational Commitment T2; CC2 - Career Commitment T2; ST - Transfer Support; MST - Material Support for Transfer; PST - Psychosocial Support for Transfer; BS - Behavioral Strategies; CAS - Cognitive-Affective Strategies; IA - Impact in Amplitude; ID - Impact in Depth. $* p<0,05 ; * * p<0,01$ 
Table 2. SEM estimated coefficients and bootstrap replications of the coefficients

\begin{tabular}{lrrrrr}
\hline \multicolumn{2}{c}{ Relationships } & \multicolumn{2}{c}{ MLE } & \multicolumn{2}{c}{ Bootstrap } \\
\hline & UC* & SC* & CR* & Average & SE* \\
\hline CWT1 $\Rightarrow$ CWT2 & 1.017 & .863 & 22.336 & 1.018 & 0.047 \\
CWT2 $\Rightarrow$ ST & 0.354 & .454 & 10.577 & 0.343 & 0.038 \\
ST $\Rightarrow$ SAWLT & 0.919 & .833 & 10.912 & 0.968 & 0.139 \\
CWT2 $\Rightarrow$ IA & 0.135 & .170 & 4.792 & 0.126 & 0.033 \\
CWT2 $\Rightarrow$ ID & 0.005 & .004 & 0.107 & -0.006 & 0.040 \\
ST $\Rightarrow$ IA & 0.065 & .064 & 0.552 & 0.192 & 0.264 \\
ST $\Rightarrow$ ID & 0.082 & .051 & 0.444 & 0.262 & 0.409 \\
SAWLT $\Rightarrow$ IA & 0.610 & .662 & 6.115 & 0.519 & 0.204 \\
SAWLT $\Rightarrow$ ID & 0.979 & .680 & 6.216 & 0.851 & 0.317 \\
& & & & &
\end{tabular}

Note. $\mathrm{UC}=$ Unstandardized Coefficient; $\mathrm{SC}=$ Standardized Coefficient; $\mathrm{CR}=$ Critical Ratio; Average $=$ Estimation mean in bootstrap samples; $\mathrm{SE}=$ Standard Error CWT1 $=$ Commitment at Work before Training T1; OCl = Organizational Commitment T1; CC1 = Career Commitment T1; CWT2 = Commitment at Work after Training T2; OC2 = Organizational Commitment T2; CC2 $=$ Career Commitment T2; ST = Transfer Support; MST = Material Support for Transfer; PST $=$ Psychosocial Support for Transfer; SAWLT = Strategies for the Application at Work of what was Learned during Training; BS = Behavioral Strategies; CAS = Cognitive-Affective Strategies; IA = Impact in Amplitude; ID = Impact in Depth

variables were obtained by SAWLT, followed by ST and CWT2.

There is a group of extremely elevated standard deviation values for the estimation of these coefficients in the bootstrap samples (highlighted cells in Table 2), indicating a suppressor effect (Maassen \& Bakker, 2001), between the ST variables and SAWLT. This effect can be observed by the accentuated variance in the estimation of the predictive relationships of SAWLT and ST over the effectiveness measures. Suppression among the variables can also be identified due to the elevated correlation among these variables (Table 1). Despite the robustness of structural equation modeling in relation to the suppression effect (Maassen \& Bakker, 2001), this effect produced a negative influence on the prediction of ST over effectiveness.

In order to diminish doubts related to overlapping between the measures of support for transfer and strategies for the application of what was learned, an exploratory factor analysis (EFA) was done using the MLE (Maximum Likelihood Estimation) method. In this analysis, the correlation matrix between items from both measurement instruments was considered. The results have indicated that the empirical structures of the scales do not overlap, since all items have correctly saturated into their original factors, revealing clear distinctions among the measurement instruments.

The goodness of fit indices for the structural equation model are good $[\mathrm{CFI}=.987 ; \mathrm{GFI}=.976 ; \mathrm{RMR}=$ .001 ; RMSEA $=.053(.038 ; .068)]$. This is true for comparative and residual measures. The value obtained for RMSEA may be considered acceptable, given criteria discussed by authors such as McDonald and Ho (2002). The high RMSEA test power indicates that the decision in relation to the test of the close adjustment hypothesis was correct (Hancock \& Freeman, 2001; MacCallum, Browne \& Sugawara, 1996). The residuals are small, which can be noted by the low residual index values.

\section{Discussion}

The model (Figure 2) was tested and the goodness of fit indices were obtained. The expected predictions were tested. Corroborations for most hypotheses were obtained (Table 3). However, this study possesses some limitations that must be highlighted: (a) lack of generalizability to other organizational contexts; (b) the reported suppression effect, and (c) the solely use of self report measures of the criterion variables. In the future, these should be avoided through diversification in data collection procedures and measurement instruments, as well as through the increase of the sample size by including other organizations.

A significant part of the literature on TD\&E heavily relies on theoretical models which are derived from systems theory, for needs assessment, adult learning and instructional psychology, for TD\&E design and implementation, and program evaluation, for determining its effectiveness. However, the present evidences demonstrate the important role played by organizational behavior variables, such as worker commitment and perception of organizational support, over training effectiveness.

These two variables have their roots in other knowledge fields, especially social psychology. Commitment may remain stable, from the participation in training courses until ex-trainees try to transfer learning, when they are back to work ( $\mathrm{H} 1$ has been corroborated). However, this attitude may be deeply associated to how these individuals perceive support for transfer $(\mathrm{H} 2$ has also been corroborated) and decide to use at work what they have learned in training (H3 has been partially corroborated). The role of perception of support has been demonstrated to be critical, for training effectiveness and for the use of strategies for the application of learning and in both cases the explanation for it is based on reciprocity theory, another key element of contemporary social psychology.

Affect, an essential component of commitment, may "...play a more central role in the training process in general", as it has been predicted by Aguinis and Kraiger (2009, p. 469). Perceptions concerning supportive work environments may play two roles in this process, on increasing the use of strategies for transfer (refuting H4) and on training effectiveness itself (corroborating H6). This calls attention to the importance of organizational support theory (Eisenberger, Huntington, Hutchinson \& Sowa, 1986; Rhoades \& Eisenberger, 2002) for the understanding of human behavior at work. Individual performance after train- 
Table 3. Hypotheses and their empirical corroboration

\begin{tabular}{|c|c|c|c|}
\hline Hypothesis & Description & Corroboration & Theoretical Implications \\
\hline $\mathrm{H}_{1}$ & $\begin{array}{l}\text { Commitment at work } \\
\text { before training will be } \\
\text { positively related to } \\
\text { commitment after training. }\end{array}$ & Corroborated & $\begin{array}{l}\text { Commitment tends to remain stable before and after training, as it has already been suggestec } \\
\text { by other studies (e.g. Coyle-Shapiro, 1999). }\end{array}$ \\
\hline $\mathrm{H}_{2}$ & $\begin{array}{l}\text { Commitment at work after } \\
\text { training will predict } \\
\text { positively perception of } \\
\text { support for transfer. }\end{array}$ & Corroborated & $\begin{array}{l}\text { More commitment at work is associated with the perception of support for transfer, as pro- } \\
\text { posed by reciprocity theory (Abbad, Pilati and Borges-Andrade, 1999). }\end{array}$ \\
\hline $\mathbf{H}_{3}$ & $\begin{array}{l}\text { Commitment at work } \\
\text { after training will predict } \\
\text { positively trainingeffec- } \\
\text { tiveness at work. }\end{array}$ & Partial & $\begin{array}{l}\text { Organizational and career commitment was a predictor of impact in amplitude. But it did } \\
\text { not predict in depth impact. The latter measure of impact is closely related to instructional } \\
\text { design features, while the two former measures are more related to working features. This } \\
\text { might explain these results. Attitudes with a focus on the organization and the career are } \\
\text { closely related to work, instead of instruction (or learning). }\end{array}$ \\
\hline $\mathrm{H}_{4}$ & $\begin{array}{l}\text { Perception of support } \\
\text { for transfer will be a } \\
\text { negative predictor of } \\
\text { strategies for the } \\
\text { application of learning. }\end{array}$ & Refuted & $\begin{array}{l}\text { The initial theoretical assumption was that more strategies to apply what have been } \\
\text { learned would appear among those who would perceive less support. However, the empi- } \\
\text { rical finding may be explained by the use of an alternative hypothesis based on reciprocity } \\
\text { theory (Abbad, Pilati and Borges-Andrade, 1999): individuals who perceive a supportive } \\
\text { environment increase their effort to apply what they have learned. }\end{array}$ \\
\hline $\mathrm{H}_{5}$ & $\begin{array}{l}\text { Strategies for the } \\
\text { application of learning } \\
\text { will be a positive } \\
\text { predictor of training } \\
\text { effectiveness at work. }\end{array}$ & Corroborated & $\begin{array}{l}\text { Individuals may actively increase training effectiveness if they are able to transform their } \\
\text { environment, so that it becomes "supportive"(Burke, 1997; Gist, Stevens and Bavetta, } \\
\text { 1991; Morin and Latham, 2000; Richman-Hirst, 2001; Stevens and Gist, 1997; } \\
\text { Wexley and Baldwin, 1986). }\end{array}$ \\
\hline $\mathrm{H}_{6}$ & $\begin{array}{l}\text { Perception of support } \\
\text { for transfer will be } \\
\text { a positive predictor of } \\
\text { training effectiveness at }\end{array}$ & Corroborated & $\begin{array}{l}\text { Despite the statistical suppression effect, the hypothesis was corroborated. This is coherent } \\
\text { with several studies in the area, according to Abbad, Pilati and Pantoja (2003), Aguinis and } \\
\text { Kraiger (2009) and Salas and Cannon-Bowers (2001). }\end{array}$ \\
\hline
\end{tabular}

ing is just part of it. However, more empirical evidence is needed for the test of this theory as an explanation for the use of application strategies of what has been learned.

For several years, perception of support (climate) for transfer has been revealed as an extremely relevant predictor of training effectiveness (Abbad, Pilati \& Pantoja, 2003; Aguinis \& Kraiger, 2009; Salas \& Cannon-Bowers, 2001). Therefore, the organizational context (or the perception of it), would be playing a key role for TD\&E. This is not new, it is an assumption from systems theory, which has been used for several decades in organizational psychology. It should not be forgotten, however, that commitment at work, a stable employee attitude, was found in association with that perception and with training effectiveness itself.

The present study showed that application strategies by individuals ( $\mathrm{H} 5$ corroborated), along with that perception of support (H6 corroborated), have high predictive power over training effectiveness. Few studies have focused on the association between egresses' strategies for the increase of transfer and effects of training at work (e.g. Hutchins \& Burke, 2006). Therefore, along with managers who usually have a high control over organizational context, or the perception of it by individuals, these individuals may be active self managers of training effectiveness. The other novelty here is that those strategies may consist of spontaneous actions which can be increased by the perception of support for transfer, instead of the perception of absence of support ( $\mathrm{H} 4$ refuted).

The overall results suggest three theoretical elements to be considered in a model that explains effectiveness of TD\&E: (a) affect (organizational and career commitments); (b) cognition (perception of psychosocial and material support for the transfer of what has been learned), and (c) action (cognitive-affective and behavioral strategies for applying what has been learned). Taking into account these elements is relevant for structuring a parsimonious integrated theory on the effectiveness of TD\&E within the discipline of organizational behavior. The building of such a theory should consider the organizational system, as well as the foundations of human behavior at work. New studies should follow the path in order to build a frame of reference for explaining TD\&E effectiveness which might be used in evaluation models that allow for frugal technological developments. 
In summary the theoretical contributions of this paper are twofold: (a) the active role of the trainee in the post training environment as a relevant factor to increase the training effectiveness, even when there is no formal training to develop application strategies; and (b) the positive association between perception of support for transfer and application strategies, suggesting that a more supportive environment may increase the use of application strategies and, therefore, the proactive behavior of employees. This might, with more future research, contribute to the consolidation of an integrated theory of training effectiveness. A theory that would have its roots in several different knowledge fields.

The comprehension of the effectiveness of TD\&E actions is rigorously linked to human behavior at work, keeping in mind that TD\&E actions are designed, in the first place, to promote behavior changes. The field should advance in empirical studies, aiming at the production of technologies for the resolution of practical problems in organizations. A needed technology, which could have been thought as a consequence of findings from the present study, would be one for developing, in individuals, the capacity to use strategies for the application of what has been learned at work.

\section{References}

Abbad, G. (1999). Um modelo integrado de avaliação de impacto de treinamento no trabalho. [An integrated evaluation model of the impact of of training on work]. Unpublished doctoral dissertation. University of Brasilia, Brasilia, Brazil.

Abbad, G., Borges-Andrade, J. E., \& Sallorenzo, L. H. (2004). Self-assessment of training impact at work: validation of a measurement scale. Interamerican Journal of Psychology, 38, 277-284.

Abbad, G., Pilati, R. \& Borges-Andrade, J. E. (1999). Percepção de suporte organizacional: Desenvolvimento e validação de um questinário. [Perception of organizational support: Development and validation of a measure]. Revista de Administração Contemporânea, 3, 29-51. doi: 10.1590/S1415-655-1999000200003

Abbad, G., Pilati, R. \& Pantoja M. J. (2003). Avaliação de treinamento: análise da literatura e agenda de pesquisa. [Evaluation of training: analysis of the literature and research agenda]. Revista de Adminstração da USP, 38, 205-218.

Aguinis, H. \& Kraiger, K. (2009). Benefits of training and development for individuals and teams, organizations, and society. Annual Review of Psychology, 60, 451-474. doi:10.1146/annurev.psych.60.11070-7.163505

Arbukle, J. L. \& Worthke, W. (1999). AMOS 4.0 users guide. SPSS: EUA.

Arthur Jr., W., Bennet Jr., W., Edens, P. S., \& Bell, S. T. (2003). Effectiveness of training in organizations: a meta- analysis of design and evaluation features. Journal of Applied Psychology, 88, 234-245. doi:10.1037/00219010.88.2.234

Axtell, C. M., Maitlis, S., \& Yearta, S. K. (2000). Predicting transfer of training: an exploratory study of immediate and longer term influences. Unpublished manuscript, Work Psychology Institute, University of Sheffield, Sheffield, United Kingdom.

Baldwin, T. T. \& Ford, J. K. (1988). Transfer of training: a review and directions for future research. Personnel Psychology, 41, 63-105. doi:10.1111/-j.1744-6570.1988. tb00632.x

Bastos, A. V. B. (1998). Comprometimento no trabalho: Contextos em mudança e os rumos da pesquisa neste domínio [Commitment at work: Contexts in change and the fields of study in this area]. [CD-Rom]. Proceedings of the XXII ENANPAD.

Birdi, K., Allan, C., \& Warr, P. (1997). Correlates and perceived outcomes of four types of employee development activity. Journal of Applied Psychology, 82, 845-857.doi: 10.1037/0021-9010.82.6.845

Blau, G. J. (1985). The measurement and prediction of career commitment. Journal of Occupational Psychology, 58, 277-288.

Bollen, K. A. (1990). Overall fit in covariance structure models: two types of sample size effects. Psychological Bulletin, 107, 256-259.doi: 10.103-7/0033-2909.107.2. 238

Boomsma, A. (2000). Reporting analyses of covariance structures. Structural Equation Modeling, 7, 461-483.

Borges-Andrade, J. E. (2006). Avaliação integrada e somativa em TD\&E. [Integrated and Summative Evaluation in TD\&E]. In J. E. Borges-Andrade, G. S. Abbad \& L. Mourão (eds), Treinamento, Desenvolvimento $e$ Educação em Organizações e Trabalho: fundamentos para a gestão de pessoas [Training, Development and Education in Organizations and Work: foundations for personnel management] (pp.343-358). Porto Alegre, Brazil: Artmed.

Borges-Andrade, J. E., Pilati, R. (2001). Comprometimento atitudinal e comportamental: Relações com suporte e imagem nas organizações [Behaviorial and atitudinal commitiment: Relations with organizational support and organizational images]. Revista de Administração Contemporânea, 5, 85-106.

Burke, L. (1997). Improving positive transfer: A test of relapse prevention training on training outcomes. Human Resource Development Quarterly, 8, 115-128.doi: 10.1002/hrdq.3920080204

Byrne, B. (2001). Structural equation modeling with Amos: Basic concepts, applications and programming. New Jersey: Lawrence Erlbaum \& Associates.

Cheng, E. W. L. \& Ho, D. C. K. (2001). The influence of job and career attitudes on learning motivation and transfer. Career Development International, 6, 20-28.doi: 10. 1108/13620430110381007

Cooper-Hakim, A., Viswesvaran, C. (2005). The construct of work commitment: testing an integrative framework. Psy- 
chological Bulletin, 131, 241-259. doi:10.1037/00332909.131.2.241

Coyle-Shapiro, J. A. M. (1999). Employee participation and assessment of an organizational change intervention. Journal of Applied Behavioral Science, 35, 439-456. doi: 10.1177/002188639-9354006

Efron, B. \& Tibshirani, R. J. (1993). An introduction to the bootstrap. Miami: Chapman \& Hall.

Eisenberger, R., Huntington, R., Hutchinson, S. \& Sowa, D. (1986). Perceived organizational support. Journal of Applied Psychology, 71, 500-507. doi:10.1037/00219010.71.3.500

Gist, M. E., Stevens, C. K., \& Baveta, A. G. (1991). Effects of self-efficacy and post-training intervention on the acquisition and maintenance of complex interpersonal skills. Personnel Psychology, 44, 837-861. doi: 10.1111/ j.1744-6570.1991.tb00701.x

Goldstein, I. L. (1993). Training in organizations. Los Angeles: Pacific Grove.

Hancock, G. R. \& Freeman, M. J. (2001). Power and sample size for the root mean square error of approximation test of not close fit in structural equation modeling. Educational and Psychological Measurement, 61, 741758. doi: 10.1177/00131-640121971491

Holton III, E. F., Bates, R. A., Seyler, D. L., \& Carvalho, M. B. (1997). Toward construct validation of a transfer climate instrument. Human Resource Development Quarterly, 8, 95-113. doi: 10.1002/hrdq.3920080203

Hutchins, H. M. \& Burke, L. A. (2006). Has relapse prevention received a fair shake? A review and implications for future transfer research. Human Resource Development Review, 5, 8-24. doi: 10.1177/1534484305284316

Kaplan, D. (2000). Structural Equation Modeling: foundations and extensions. Thousand Oaks: Sage.

Kirkpatrick, D. L. (1976). Evaluation of training. In R. L. Craig (Ed.), Training and development handbook (pp. 301-319). New York: McGraw-Hill.

Klein, H. J.; Becker, T. E., \& Meyer, J. P. (2009). Commitment in organizations: accumulated wisdom and new directions. Florence, KY: Routledge/Taylor and Francis Group.

Latham, G. P \& Heslin, P. A. (2003). Training the trainee as well as the trainer: Lessons to be learned from clinical psychology. Canadian Psychology, 44, 218-231. doi: 10.1037/h0086943

Little, R. J. A. \& Rubin, D. B. (1987). Statistical analysis with missing data. New York: Lawrence Erlbaum.

Maassen, G. H. \& Bakker, A. B. (2001). Suppressor variables in path models. Sociological Methods \& Research, 30, 241-270. doi:10.1177/0049124-101030002004

MacCallum, R. C., Browne, M. W., \& Sugawara, H. M. (1996). Power analysis and determination of simple size for covariance structure modeling. Psychological Methods, 1, 130-149. doi:10.103-7/1-082-989X.1.2. 130

McDonald, R. P. \& Ho, M. R. (2002). Principles and practice in reporting structural equation analyses. Psychological Methods, 7, 64-82. doi:10.1037/108-2-989X.7.1.64
Mardia, K. V. (1971). The effect of nonnormality on some multivariate tests and robustness to nonnormality in the linear model. Biometrika, 58, 105-121.

Marx, R. D. (1982). Relapse prevention of managerial training: A model for maintenance of behavior change. Academy of Management Review, 7, 433-441.

Milne, D., Westerman, C., \& Hanner, S. (2002). Can a "Relapse Prevention" module facilitate the transfer of training? Behavioral and Cognitive Psychotherapy, 30, 361-364. doi:10.1017/S13524-65802003119

Morin, L. \& Latham, G. P. (2000). The effect of mental practice and goal setting as a transfer of training intervention on supervisor's self-efficacy and communication skills: An exploratory study. Applied Psychology: An International Review, 49, 566-578.

Mowday, R. T., Steers, R. M., \& Porter, L. W. (1979).The measurement of organizational commitment. Journal of Vocational Psychology, 14, 224-247.

Osborne, J. (2002). Notes on the use of data transformations. Practical Assessment, Research \& Evaluation. Advanced online publication.

Pilati, R. \& Abbad, G. (2005). Análise fatorial confirmatória da escala de impacto do treinamento no trabalho. [Confirmatory factor analysis for the training impact on workscale]. Psicologia: Teoria e Pesquisa, 21, 43-51. doi:10.1590/S0102-3772200-5000100007

Pilati, R. \& Borges-Andrade, J. E. (2005). Estratégias para a aplicação no trabalho do aprendido em treinamento: proposição conceitual e desenvolvimento de uma medida. [Strategies for the application at work of what was learned in training: conceptual proposal and measure development]. Psicologia Reflexão e Crítica, 18, 207214. doi: 10.1590/S0102-797220-05000200009

Pilati, R. \& Palomero, C. (2009). Validación y test de la equivalencia de la estructura factorial de la escala de estrategias de aplicación de lo aprendido [Validation and equivalence test of factorial structure of work applications trategies scale]. Interamerican Journal of Psychology, 43, 39-48.

Rhoades, L. \& Eisenberger, R. (2002). Perceived organizational support: A review of literature. Journal of Applied Psychology, 87, 698-714. doi: 10.1037/00-21-9010.87. 4.698

Richman-Hirsch, W. L. (2001). Posttraining interventions to enhance transfer: The moderating effects of work environments. Human Resource Development Quarterly, 12, 105-120. doi: 10.1002/hrdq.2

Rodrigues, A. G. (2000). A Natureza da participação e suas implicações no impacto do treinamento no trabalho. [The nature of participation and its implications for the impact of training on work]. Master's thesis, Psychology Institute, University of Brasilia, Brasilia, Brazil.

Rouiller, J. Z. \& Goldstein, I. L. (1993).The relationship between organizational transfer, climate and positive transfer of training. Human Resource Development Quarterly, 4, 377-390. doi:10.1002/-hrdq.3920040408

Ryle, G. (1949). The concept of mind. London: Hutchinson. Salas, E. \& Cannon-Bowers, J. A. (2001). The science of 
training. Annual Review of Psychology, 52, 471-499. doi:10.1146/annurev.psych.52.1.471

Stevens, C. K. \& Gist, M. E. (1997). Effects of self-efficacy and goal-orientation training on negotiation skill maintenance: What are the mechanisms? Personnel Psychology, 50, 955-978. doi:10.1111/-j.1744-6570.1997.tb01490.x
Tabachnick, B. \& Fidell, L. S. (2001). Using multivariate statistics. San Francisco: Allyn \& Bacon.

Wexley, K. N. \& Baldwin, T. T. (1986). Post-training strategies for facilitating positive transfer: An empirical exploration. Academy of Management Journal, 29, 503520.

Manuscript Received: 26/07/2011

Revision Received: 01/02/2012

Accepted: 01/03/2012 